\title{
Protist (Coccidia) and Related Diseases
}

\author{
Sheila Castellanos-Martínez, Camino Gestal, Santiago Pascual, \\ Ivona Mladineo, and Carlos Azevedo
}

\begin{abstract}
Coccidia of the genus Aggregata is the most widely distributed coccidian in cephalopods. Damages caused to the hosts include mechanical (tissue injury), biochemical (malfunction of digestive enzymes), and molecular (affects cellular immune response) effects. However, coccidiosis is not a fatal disease to the cephalopod host; it severely weakens its innate immunity making it vulnerable to secondary infections. Therefore, coccidia of the genus Aggregata are considered the most dangerous parasite for cephalopods affecting wild species of notable economic importance for fishery and aquaculture activity. The pathology caused by coccidiosis to the most important European cephalopod species is the subject of the present chapter.
\end{abstract}

\section{Keywords}

Cephalopods - Diseases $\cdot$ Histopathology - Ultrastructure $\cdot$ Coccidian $\cdot$ Apicomplexa

S. Castellanos-Martínez ( $\square)$

Instituto de Investigaciones Oceanológicas, UABC, Ensenada, 22860, Mexico

e-mail: mixtly2000@ hotmail.com

C. Gestal

Aquatic Molecular Pathobiology Department, Institute of Marine Research, Spanish National Research Council (CSIC), 36208

Vigo, Pontevedra, Spain

e-mail: cgestal@iim.csic.es

S. Pascual

Ecology and Biodiversity Group, Institute of Marine Research, Spanish National Research Council (CSIC), 36208 Vigo,

Pontevedra, Spain

e-mail: spascual@iim.csic.es

\section{Mladineo}

Institute of Oceanography and Fisheries, 21000 Split, Croatia

e-mail: mladineo@izor.hr

\section{Azevedo}

Laboratory of Cell Biology, Institute of Biomedical Sciences (ICBAS/uP), University of Porto, 4050-013 Porto, Portugal

e-mail: azevedoc1934@gmail.com

\subsection{Introduction}

Cephalopods are hosts for several parasitic organisms. Although most of them are known for scientific community, gaps with respect to their entire biology remain. Coccidian protozoans of the phylum Apicomplexa are among the commonest parasites infecting the digestive tract of cephalopods; however, a limited number of species have been described worldwide. All of them are included in the genus Aggregata. Their life cycle requires an intermediary host, a crustacean, and a definitive host, the cephalopod, where the parasite develops into the infective stage, the esporozoites, which are contained inside the sporocysts that are released to the ocean in the feces of the cephalopod host. The apparent simplicity of coccidia becomes a challenge to clarify very basic aspects that are not yet clear such as taxonomy, phylogeny, life cycle, distribution or effects on their hosts. Two coccidia species, Aggregata octopiana and Aggregata eberthi, both infecting European hosts are the best know species to date. Coccidiosis 
is highly prevalent in most of the studied cephalopod hosts and reaches severe levels of infection that compromise the host well-being at functional, biochemical, and molecular levels. Traditional techniques of detection are still used until advanced protocols are being designed. Detection of coccidiosis is particularly important in species of aquaculture relevance such as Octopus vulgaris and Sepia officinalis, both caught from the wild for rearing and naturally infected by Aggregata spp. Hence, the study of coccidiosis in cephalopods including characterization, detection, and eradication of the parasite is under research. The mentioned protistan that infects cephalopods hosts is far from being well known. However, the up-to-date knowledge regarding biological aspects of the parasites and histopathological damage caused to the cephalopod host is presented in this chapter.

\subsection{Etiology and Epidemiology}

Coccidiosis is caused by an obligate, intracellular protozoa classified in the phylum Apicomplexa, family Aggregatidae. To date, 10 species have been described worldwide in octopus, squid, and cuttlefish, being Aggregata the single genus recognized (Table 9.1), and all the species known are parasites causative of coccidiosis (Hochberg 1983). The intensity of infection can be as high as $82 \times 10^{6}$ sporocyst/digestive tissue of the cephalopod host (Pascual et al. 1996; Gestal 2000). The prevalence of infection varies among the cephalopod species. The highest prevalence (98$100 \%$ ) is recorded in O. vulgaris and S. officinalis (Pascual et al. 1996). In contrast, the lowest prevalence of infection (3\%) has been recorded in the flying squid, Todarodes sagittatus and all of them in the NE Atlantic (Gestal et al. 2000). In the wild $O$. vulgaris from Adriatic and Ionian seas, $100 \%$ of prevalence were observed, whereas $98 \%$ were recorded in octopuses from Tyrrhenian Sea with no mortalities associated with coccidiosis reported from both localities (Tedesco et al. 2017).

Identification of Aggregata spp. relies on the morphological characterization of sporogonial stages (size, shape, number of sporozoites per sporocyst and ornamentation sporocyst) and parasite-host specificity. To date, the best known species are A. octopiana, parasite of $O$. vulgaris, and A. eberthi, which infects $S$. officinalis. A. octopiana characterizes because of the spiny sporocyst and eight sporozoites inside each. In contrast, smooth sporocysts harboring three sporozoites characterize A. eberthi (Fig. 9.1) (Dobell 1925; Gestal et al. 1999). The Aggregata species from the

Table 9.1 Aggregata species recorded worldwide in cephalopod hosts. (-) denotes not available

\begin{tabular}{|c|c|c|c|c|c|c|}
\hline Aggregata sp. & Hosts & Localities & Cyst wall & $\begin{array}{l}\text { Sporozoites } \\
\text { number }\end{array}$ & $\begin{array}{l}\text { GenBank accession } \\
\text { number }\end{array}$ & References \\
\hline \multirow[t]{3}{*}{ octopiana } & \multirow[t]{3}{*}{ O. vulgaris } & Mediterranean & Spiny/smooth & 8 & LC186909-LC186925 & Tedesco et al. (2017) \\
\hline & & NW Atlantic & Spiny & 8 & KC188342 & $\begin{array}{l}\text { Gestal et al. (1999); } \\
\text { Castellanos-Martínez et al. } \\
\text { (2013) }\end{array}$ \\
\hline & & Adriatic Sea & - & - & DQ096837 & Kopečná et al. (2006) \\
\hline \multirow[t]{2}{*}{ eberthi } & \multirow[t]{2}{*}{ S. officinalis } & NE Atlantic & Smooth & 3 & KC188343 & $\begin{array}{l}\text { Labbé (1895); } \\
\text { Castellanos-Martínez et al. } \\
\text { (2013) }\end{array}$ \\
\hline & & Adriatic Sea & Smooth & - & DQ096838 & Kopečná et al. (2006) \\
\hline bathytherma & $\begin{array}{l}\text { Vulcanoctopus } \\
\text { hydrothermalis }\end{array}$ & NE Pacific & Smooth & $14-17$ & - & Gestal et al. (2010) \\
\hline andresi & $\begin{array}{l}\text { Martialia } \\
\text { hyadesi }\end{array}$ & SW Atlantic & Smooth & 3 & - & Gestal et al. (2005) \\
\hline patagonica & $\begin{array}{l}\text { Enteroctopus } \\
\text { megalocyatus }\end{array}$ & SW Atlantic & Smooth & 8 & - & Sardella et al. (2000) \\
\hline valdesensis & $\begin{array}{l}\text { Octopus } \\
\text { tehuelchus }\end{array}$ & SW Atlantic & - & $4-8$ & - & Sardella et al. (2000) \\
\hline sagittata & T. sagittatus & NE Atlantic & Smooth & $4-8$ & - & Gestal et al. (2000) \\
\hline dobelli & $\begin{array}{l}\text { Enteroctopus } \\
\text { dofleini }\end{array}$ & NE Pacific & Smooth & $9-22$ & - & Poynton et al. (1992) \\
\hline millerorum & $\begin{array}{l}\text { Octopus } \\
\text { bimaculoides }\end{array}$ & NE Pacific & Smooth & $8-10$ & - & Poynton et al. (1992) \\
\hline kudoi & Sepia elliptica & NW Indian & Smooth & $6-12$ & - & Narasimhamurti (1979) \\
\hline
\end{tabular}


Fig. 9.1 Comparison of the number of sporozoites per sporocyst. a Histological section of $O$. vulgaris cecum showing eight sporozoites of A. octopiana. b Histological section of $S$. officinalis cecum showing three sporozoites of A. eberthi. Scale bars a $15 \mu \mathrm{m} ; \mathbf{b} 20 \mu \mathrm{m}$


Adriatic differs morphologically from those in the NE Atlantic, Tyrrhenian, and Ionian seas in the appearance of the cyst wall (smooth in the former, spiny in the latter) and some minor variations in the size of oocysts and sporocysts (Tedesco et al. 2017). All the species show the same number of sporozoites (being eight), and the characterization of the SSU rRNA gene that complements morphological and morphometric descriptions provides molecular support that distinguish among Aggregata species from NE Atlantic, Adriatic, Ionian, and Tyrrhenian seas (Kopečná et al. 2006; Castellanos-Martínez et al. 2013; Tedesco et al. 2017). Phylogeny indicates three lineages of which Adriatic isolates significantly separated from those of the Ionian and Tyrrhenian seas although being more related to Ionian isolates than the rest. These observations all together evidence the existence of different Aggregata species or subspecies complex in octopuses from different seas (Tedesco et al. 2017).

\subsection{Pathogenesis}

Coccidiosis is a disease that affects the digestive tract of cephalopods. The Aggregata spp. life cycle is heteroxenous; asexual merogonial stages develop inside the gut of the intermediate host, which is a crustacean (Fig. 9.2). The infective stage called merozoite invades the intestinal mucosa of the crustaceans and develops intracellularly into meronts that remains awaiting until the intermediate host is eaten by the cephalopod. Merogonial stages ingested by the cephalopod are able to infect the whole digestive tissue tract of the mollusk and epithelial cells in additional tissues. Unusual organs of infection such as the connective tissue of gills, mantle, arms, visceral mass and mesentery of the host have been recorded when it harbor an intense infection. It is named extraintestinal coccidiosis, and most of the time, it is macroscopically identified because the presence of white oocysts on the tissue (Figs. 9.3 and 9.4) simply opening gently the mantle cavity of the cephalopod (Sykes and Gestal 2014). Extraintestinal infection has been recorded in cephalopods reared in floating cages from the NE Atlantic. Either the site of extraintestinal infection, the parasite causes hypertrophy of invaded cells, hemocytic infiltration and activates phagocytosis by hemocytes (Fig. 9.5) (Gestal et al. 2002a; Pascual et al. 2006). In the Adriatic Sea, Aggregata spp. has been also identified in experimentally reared $O$. vulgaris (250-500 g) fished from wild (Island of Brač, Adriatic Sea) and held individually in $4 \mathrm{~m}^{2}$ concrete tanks. After 8 months of rearing without expected weight gain, animal ceased the feeding, became excitated and aggressive, lacked the capacity of camouflage, and developed epidermal lesions on the mantle and arms (Fig. 9.5), with visible miliary protozoan oocysts (Mladineo and Jozić 2005). Extraintestinal gamogonial and sporogonial Aggregata stages infecting arms and gills triggered notable infiltrated hemocytes and replacement of the host tissue (Mladineo and Bočina 2007).



Fig. 9.2 Merogonial (mr) stages of A. octopiana infecting the gut of Palaemon serratus (Bismark brown stain). Scale bars $100 \mu \mathrm{m}$ 
Fig. 9.3 Macroscopical detection of A. octopiana in $O$. vulgaris. a Gross observation of white oocysts (arrows) on the muscle of the siphon and visceral mass. b Detail of white round and ovoid oocysts observed infecting the visceral mesentery. c White round oocyst (arrows) observed infecting the serosa on the octopus gut


After merogonial stages are ingested by the cephalopod, the establishment of the infection inside the mollusk takes place. The infection initiates with gamogony, the formation of gametes, which occurs by unequal fission of merozoites inside the cephalopod digestive tract. Macrogametes (P) and microgametes $\left(\sigma^{\prime}\right)$ are formed. The macrogamete is the most conspicuous one due to their round to ovoid in shape, central nucleus, and large nucleolus that stains darker than the rest of the cell when H\&E is used (Fig. 9.6). Although the infection can be recorded in the whole digestive tract of the mollusk, no infection is recorded in the stomach because


Fig. 9.4 Detailed macroscopic observation of A. octopiana oocysts. a White round and ovoid oocysts of A. octopiana. b Purified sporocyst of A. octopiana observed by light microscopy. c Sporozoites of A. octopiana free from the sporocyst. Scale bars a $0.4 \mathrm{~mm}$; b $15 \mu \mathrm{m}$; c $5 \mu \mathrm{m}$ the lumen is covered by a wide cuticle that reduces the nutrient intake (Garri and Lauria de Cidre 2013). A similar but thick cuticle covers the crop and esophagus (Garri and Lauria de Cidre 2013) that make nutrients and space available for infection, although in low frequency (Gestal et al. 2002a). Therefore, the target organs of infection are the non-cuticularized cecum, a tubular, spiraled organ and the gut of the cephalopod (Gestal et al. 2002a). In these tissues, the macrogamete once fertilized by a microgamete produces a zygote that in turn suffers from multiple fission, and gives rise to the sporogonial stage where oocysts, sporocysts and the infective sporozoites are formed (Gestal et al. 2002a) (Fig. 9.7). The ultrastructural analysis by transmission electron microscopy (TEM) of the sporoblast formation shows the presence of multiple nuclei inside each oocyst (Fig. 9.8), while each sporoblast has a single nucleus and a thin sporoblast cover (Fig. 9.9). The development of each sporoblast into sporocyst results in the formation of the sporozoites inside (the specific number is species specific) and a thickening of the sporocyst wall (Fig. 9.10). The infection by macrogametes and initial sporogonial stages induces a strong hemocytic infiltration, distention and rupture of the tissue infected (Fig. 9.11). The cecum wall is covered by longitudinal folds lined with cylindrical, simple, and ciliated epithelium (Garri and Lauria de Cidre 2013) that can be totally replaced by the parasite (Fig. 9.12). The infection by coccidia triggers hemocytic defensive activities such as phagocytosis of sporogonial stages, encapsulation of oocysts and gametes by flattened hemocytes and then connective tissue (Fig. 9.12) in order to isolate the parasite (Castellanos-Martínez and Gestal 2013). Mature sporocysts 
Fig. 9.5 Extraintestinal infection of A. octopiana. a Epidermal lesions on the arms of $O$. vulgaris showing visible infection by protozoan oocysts (arrow). b Detail of epidermal lesion showing numerous white oocysts of coccidia (arrow). c Connective tissue of $O$. vulgaris infected by oocyst. d Connective tissue of the octopus arm destroyed by sporogonial stages of A. octopiana and after parasite release. Scale bars $\mathbf{c}, \mathbf{d} 200 \mu \mathrm{m}$

Fig. 9.6 Gamogonial stages infecting $O$. vulgaris cecum. a Macrogametes (arrows) infecting the folds of the cecum epithelium. b Detail of macrogamete infecting the fold of O. vulgaris cecum c Comparative view of macrogametes (ma) and microgametes (mi) infecting the cecum epithelium. d Detail of microgametes infecting digestive epithelia and surrounded by hemocytes. Scale bars a $100 \mu \mathrm{m} ; \mathbf{b}$, d $30 \mu \mathrm{m}$; c $60 \mu \mathrm{m}$
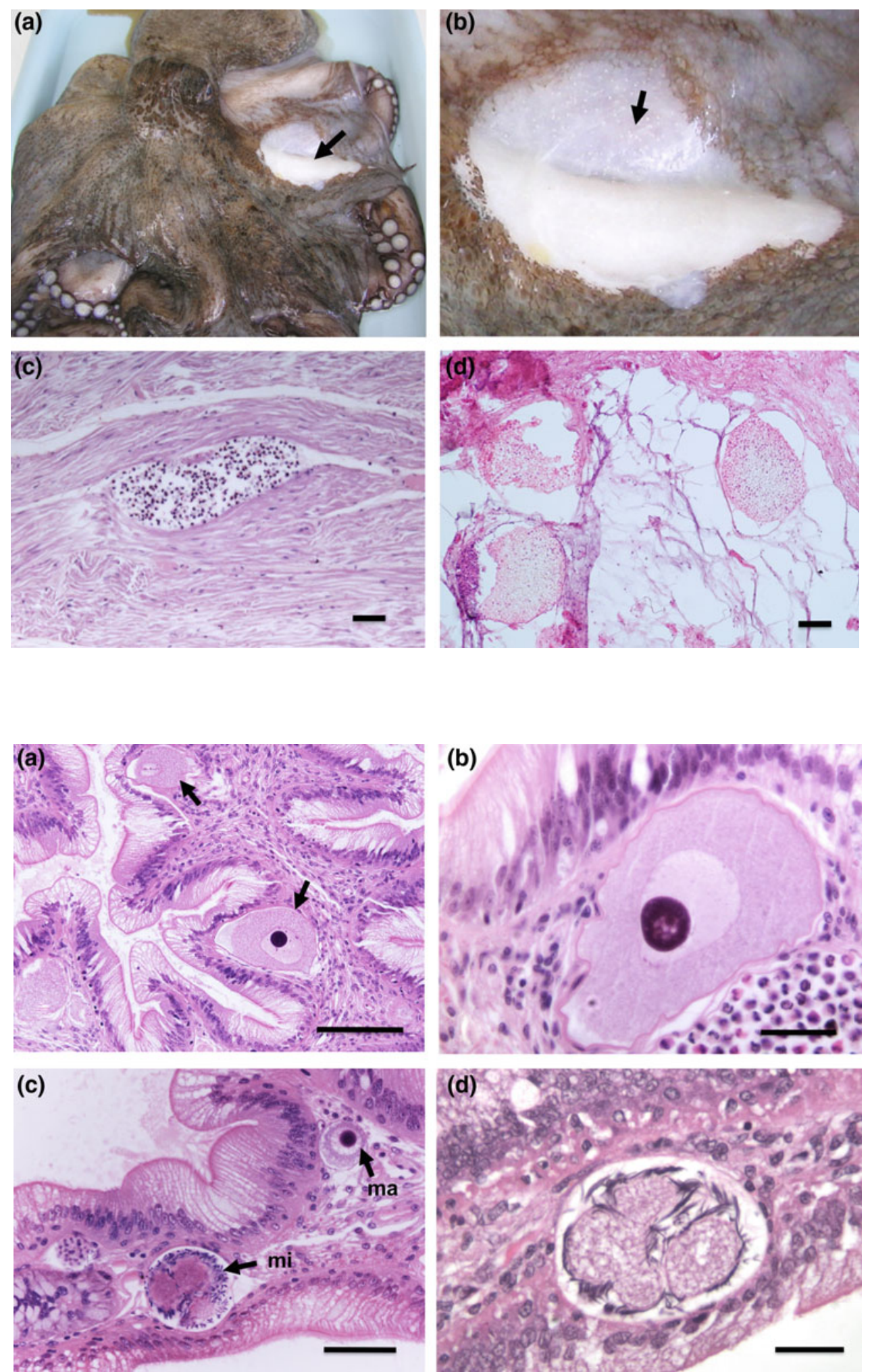



Fig. 9.7 Sporogonial development of coccidia Aggregata spp. a Zygote after starting multiple division in cecum epithelium of O. vulgaris. Note numerous hemocytes (arrowhead) that surround the parasites. b Advanced multiple division toward the formation of sporocyst. The nuclei observed in the periphery will give rise to

are released to the lumen of the cephalopod digestive tract in order to discharge the parasite to the aquatic medium in the feces of the mollusk and make them available for infecting a crustacean intermediate host (Hochberg 1983). The release of the parasite causes detachment of the epithelial cells and rupture of the connective tissue. As a result, the mucosal folds atrophy and ulcers in the digestive tissue tract of the host appear (Fig. 9.13). Coccidiosis originates acidification of the mucosal lumen that affects the stability of the digestive enzymes and nutrient absorption. It is exacerbated by the destruction of the mucosal intestinal epithelium after parasite release that also impedes the nutrient uptake of the cephalopod host (Gestal et al. 2002b). Signs of coccidiosis in cephalopods include malabsorption syndrome, decrease of cephalopod condition, the number of hemocytes, plasmatic protein, and even the concentration of copper, the respiratory pigment of hemocyanine in the hemolymph, is affected (Gestal et al. 2002b, 2007). Intense coccidiosis also alters the cephalopod immune response. Immune genes involved in pathogen recognition and regulation are up-regulated in the cecum of highly infected hosts indicating active detection of parasite-derived ligands (Castellanos-Martínez et al. 2014a). The antioxidant gene peroxiredoxin, responsible to protect sporozoites enclosed in sporocyst. c Oocyst containing immature sporocysts (arrowhead) and surrounded by hemocytes. d Oocyst with mature sporocysts of A. octopiana. Note macrogamete (m) close to the oocyst and sporozoites (s) inside sporocysts. Scale bars a, b $100 \mu \mathrm{m}$; c $200 \mu \mathrm{m} ; \mathbf{d} 10 \mu \mathrm{m}$

the host against oxidative stress, is up-regulated in the cecum of cephalopod with high parasite load. However, peroxiredoxin is weakly expressed in hemocytes of such hosts, suggesting that coccidia might suppress the respiratory burst and, thus, affect the octopus cellular immune response (Castellanos-Martínez et al. 2014a, b).

\subsection{Diagnosis}

Signs of infection are not easily visible in the infected cephalopod hosts. Gross detection of coccidia can be realized by direct observation of macroscopic white cysts when the host is highly infected (Mayo-Hernández et al. 2013), and small pieces of digestive epithelia can be observed in feces as a result of severe infection (Dobell 1925; Hochberg 1990). Fecal oocyst count is a common method for detecting coccidia, although it is not yet standardized in cephalopods. Oocyst and sporocyst detection in feces is being under standardization as a diagnostic approach in $O$. vulgaris. Presently, the challenge is focused on the design of molecular probes for detecting coccidia in the cephalopod feces that avoid the need to sacrifice the host, as is currently done, and provide certainty on experiments that uses 




Fig. 9.8 Formation of sporoblast showing multiple nuclei inside each oocyst. Ultrastructural aspects by TEM. HN: host nucleus, Pn: parasite nucleus Scale bar $8 \mu \mathrm{m}$


Fig. 9.9 Sporoblast development. Ultrastructural aspects by TEM. a Early sporoblast showing a single nucleus and a thin sporoblast cover. b Late sporoblast showing a thicker cover. Scale bars a, b $30 \mu \mathrm{m}$ 




Fig. 9.10 Phase contrast microscopy photography of A. octopiana oocyst showing inside the sporocysts containing sporozoites. Note the sporocyst (sw) and oocyst wall (ow). Scale bar $30 \mu \mathrm{m}$


Fig. 9.11 Hemocytic infiltration in the cecum epithelium of $O$. vulgaris. a Oocysts surrounded by numerous hemocytes (arrowhead) accompanied by distention (asterisk) of the tissue. b Pericyst reaction against oocyst triggered by hemocytes (arrowhead) which formed a barrier around the cysts, connective tissue (ct), distention (asterisk) of the tissue. Scale bars $\mathbf{a}, \mathbf{b} 200 \mu \mathrm{m}$
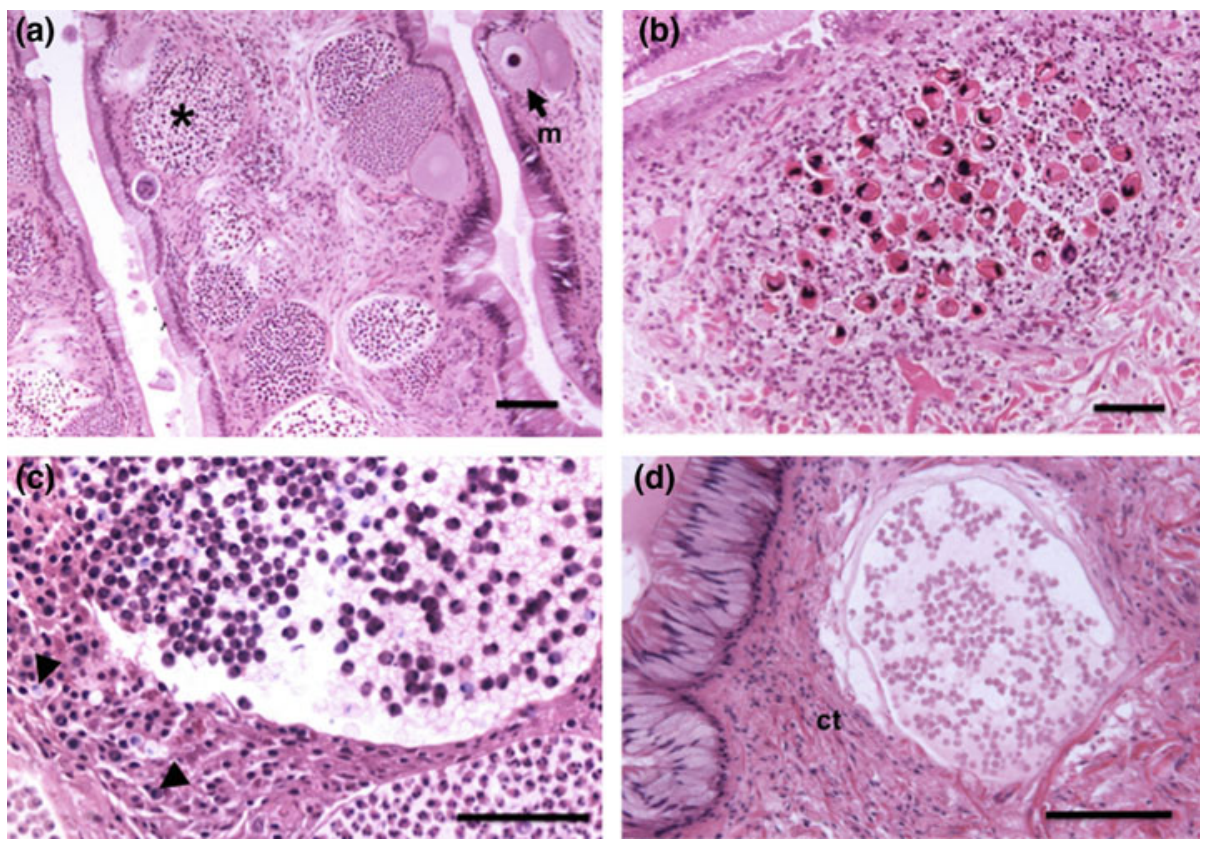

Fig. 9.12 Cecum of $O$. vulgaris infected by A. octopiana and host immune response. a Longitudinal folds of cecum showing the tissue totally replaced by coccidia at different stages of development; $\mathrm{m}$ : macrogamete, asterisk: oocyst. b Oocyst of A. eberthi phagocytosed by hemocytes. Note the lack of oocyst border and hemocytes dispersed among sporocyst c Mature oocyst of A. eberthi partially emptied and encapsulated by hemocytes. Note sporocyst (arrowhead) outside the oocyst and attacked by hemocytes. d Oocyst encysted by fibrous layer of connective tissue (ct) as a result of pericyst reaction against the parasite. Scale bars a $0.4 \mathrm{~mm}$; b $60 \mu \mathrm{m} ; \mathbf{c}, \mathbf{d} 100 \mu \mathrm{m}$ 




Fig. 9.13 Damage caused to the cecum host tissue after parasite release. a Release of $A$. octopiana sporocyst to the lumen of the host digestive tract. Note the rupture of the epithelial cells in order to release the sporocysts. b Ulcerated cecum mucosal folds in a host severely infected and after parasite release. Scale bars a, b $200 \mu \mathrm{m}$

animals alive (Gestal et al. 2002a; Sykes and Gestal 2014; Sykes et al. 2017). However, while this approach is reached, the positive detection of developmental stages of Aggregata spp. is still performed by standard histological procedure of the digestive tissue tract of dead hosts. Further stain with hematoxylin-eosin is enough to clarify the presence of parasitic stages and assess tissue damage.

\subsection{Concluding Remarks}

Coccidiosis is a common, chronic disease in cephalopods that destroy the cecum and intestinal mucosa of host, although extraintestinal infection can also affect mantle, arms, and gills connective tissue. From the 10 Aggregata species described, all of them are pathogenic and causative of coccidiosis in cephalopods that can be hard to detect. However, malabsorption syndrome, decrease in the number of hemocytes, plasmatic protein, and iron in hemolymph, as well as up-regulation of immune genes, are among the notable signs of disease and may be accompanied by discharge of small pieces of tissue lumen. The age of cephalopods when they are infected by Aggregata spp. for the first time has not been determined; however, specimens as small as $5 \mathrm{~mm}$ mantle length have been found infected in the Ria of Vigo (NW Atlantic). Any risk group based on age or length has been determined and studied for differences in severity effects of the infection. However, clear differential effects have been noted regarding the number of sporocyst infecting the digestive tract of hosts. The cephalopod rearing is still depending on wild specimens; therefore, detection of coccidian species has become an important task to prevent fattening of severely infected hosts. Preventive strategies of coccidiosis are difficult to apply in cephalopods, and no coccidiostats are available to date. Currently, avoiding the intake of infected food is the best strategy to prevent coccidia infection or reinfection, particularly, to those specimens reared in the wild.

\section{References}

Castellanos-Martínez S, Arteta D, Catarino S, Gestal C (2014a) De Novo transcriptome sequencing of the Octopus vulgaris hemocytes using Illumina RNASeq Technology: response to the infection by the gastrointestinal parasite Aggregata octopiana. PLoS ONE 9(10): e107873. https://doi.org/10.1371/journal.pone.0107873

Castellanos-Martínez S, Diz AP, Álvarez-Chaver P, Gestal C (2014b) Proteomic characterization of the hemolymph of Octopus vulgaris infected by the protozoan parasite Aggregata octopiana. J Proteomics 13(105):151-163. https://doi.org/10.1016/j.jprot.2013.12. 008

Castellanos-Martínez S, Gestal C (2013) Pathogens and immune response of cephalopods. J Exp Mar Biol Ecol 447:14-22

Castellanos-Martínez S, Pérez-Losada M, Gestal C (2013) Molecular phylogenetic analysis of the coccidian cephalopod parasites Aggregata octopiana and Aggregata eberthi (Apicomplexa: Aggregatidae) from the NE Atlantic coast using 18S rRNA sequences. Eur J Protistol 49:373-380

Dobell CC (1925) The life-history and chromosome cycle of Aggregata eberthi (Protozoa: Sporozoa: Coccidia). Parasitol 17:1-136

Garri RG, Lauria de Cidre L (2013) Microanatomy of the digestive system of Enteroctopus megalocyathus (Cephalopoda: Octopoda) of the southwest Atlantic. Bol Invest Mar Cost 42:255-274

Gestal C (2000) Epidemiología y patología de las coccidiosis en cefalópodos. Ph. D. Thesis. University of Vigo, p 157

Gestal C, Abollo E, Pascual S (2002a) Observations on associated histopathology with Aggregata octopiana infection (Protista: Apicomplexa) in Octopus vulgaris. Dis Aquat Org 50:45-49

Gestal C, Guerra A, Abollo E, Pascual S (2000) Aggregata sagittata n. sp. (Apicomplexa: Aggregatidae), a coccidian parasite from the European flying squid Todarodes sagittatus (Mollusca: Cephalopoda). Syst Parasitol 47:203-206 
Gestal C, Guerra A, Pascual S (2007) Aggregata octopiana (Protista: Apicomplexa): a dangerous pathogen during commercial Octopus vulgaris ongrowing. ICES J Mar Sci 64:1743-1748

Gestal C, Nigmatullin ChM, Hochberg FG, Guerra A, Pascual S (2005) Aggregata andresi n. sp. (Apicomplexa: Aggregatidae) from the ommastrephid squid Martialia hyadesi in the SW Atlantic Ocean and some general remarks on Aggregata spp. in cephalopod hosts. Syst Parasitol 60:65-73

Gestal C, Páez de la Cadena M, Pascual S (2002b) Malabsorption syndrome observed in the common octopus Octopus vulgaris infected with Aggregata octopiana (Protista: Apicomplexa). Dis Aquat Org 51:61-65

Gestal C, Pascual S, Corral L, Azevedo C (1999) Ultrastructural aspects of the sporogony of Aggregata octopiana (Apicomplexa, Aggregatidae), a coccidian parasite of Octopus vulgaris (Mollusca, Cephalopoda) from NE Atlantic Coast Eur J Protistol 35:417-425

Gestal C, Pascual S, Hochberg FG (2010) Aggregata bathytherma sp. nov. (Apicomplexa: Aggregatidae), a new coccidian parasite associated with a deep-sea hydrothermal ventoctopus. Dis Aquat Organ 91:237-242

Hochberg FG (1983) The parasites of cephalopods: a review. Mem Nat Mus Vict 44:109-145

Hochberg FG (1990) Diseases of Mollusca: Cephalopoda. Diseases caused by protistans and metazoans. In: Kinne O (ed) Diseases of marine animals, vol III. Cephalopoda to Urochordata. BiolŮogische Anstalt Helgoland, Hamburg, pp 47-227

Kopečná J, Jirků M, Oborník M, Tokarev YS, Lukeš J, Modrý D (2006) Phylogenetic analysis of coccidian parasites from invertebrates: search for missing links. Protist 157:173-183

Labbé A (1895) Sur le noyau et la division nucléaire chez les Benedenia. C R Acad Sci Paris, CXX, p 381

Mayo-Hernández E, Barcala E, Berriatura E, García-Ayala A, Muñoz P (2013) Aggregata (Protozoa: Apicomplexa) infection in the common octopus Octopus vulgaris from the West Mediterranean Sea: The infection rates and possible effect of faunistic, environmental and ecological factors. J Sea Res 83:195-201
Mladineo I, Bočina I (2007) Extraintestinal gamogony of Aggregata octopiana in the reared common octopus (Octopus vulgaris) (Cephalopoda: Octopodidae). J Invertebr Pathol 96:261-264

Mladineo I, Jozić M (2005) Aggregata infection in the common octopus, Octopus vulgaris (Linnaeus 1758), Cephalopoda: Octopodidae, reared in a flow-through system. Acta Adriat 46:193-199

Narasimhamurti CC (1979) The eimeriid Aggregata kudoi n. sp. from Sepia eliptica. Angew Parasitol 20:154-158

Pascual S, Gestal C, Estevez JM, Rodriguez H, Soto M, Abollo E, Arias C (1996) Parasites in commercially-exploited cephalopods (Mollusca, Cephalopoda) in Spain: an updated perspective. Aquacul 142:1-10

Pascual S, González AF, Guerra A (2006) Unusual sites of Aggregata octopiana infection in octopus cultured in floating cages. Aquacul 254:21-23

Poynton S, Reimschuesse R, Stoskopf MK (1992) Aggregata dobelli $\mathrm{n}$. sp. and Aggregata millerorum n.sp. (Apicomplexa: Aggregatidae) from two species of octopus (Mollusca: Octopodidae) from the Eastern North Pacific Ocean. J Protozool 39:248-256

Sardella NH, Ré ME, Timi JT (2000) Two new Aggregata species (Apicomplexa: Aggregatidae) infecting Octopus tehuelchus and Enteroctopus megalocyathus (Mollusca: Octopodidae) in Patagonia. Argentina. J Parasitol 86:1107-1113

Sykes AV, Almansa E, Cooke GM, Ponte G, Andrews PLR (2017) The digestive tract of cephalopods: a neglected topic of relevance to animal welfare in the laboratory and aquaculture. Front Physiol 8:492. https://doi.org/10.3389/fphys.2017.00492

Sykes AV, Gestal C (2014) Welfare and diseases under culture conditions. In: Iglesias J, Fuentes L, Villanueva R (eds) Cephalopod culture. Springer, Dordrecht, pp 97-112

Tedesco P, Gestal C, Begić K, Mladineo I, Castellanos-Martínez S, Catanese G, Terlizzi A, Fiorito G (2017) Morphological and molecular characterization of Aggregata spp. Frenzel 1885 (Apicomplexa: Aggregatidae) in Octopus vulgaris Cuvier 1797 (Mollusca: Cephalopoda) from Central Mediterranean. Protist 168:636-648
Open Access This chapter is licensed under the terms of the Creative Commons Attribution 4.0 International License (http://creative commons.org/licenses/by/4.0/), which permits use, sharing, adaptation, distribution and reproduction in any medium or format, as long as you give appropriate credit to the original author(s) and the source, provide a link to the Creative Commons licence and indicate if changes were made.
The images or other third party material in this chapter are included in the chapter's Creative Commons licence, unless indicated otherwise in a credit line to the material. If material is not included in the chapter's Creative Commons licence and your intended use is not permitted by statutory regulation or exceeds the permitted use, you will need to obtain permission directly from the copyright holder. 